\title{
Correction to: Detailed prediction of protein sub-nuclear localization
}

Maria Littmann ${ }^{1 *}+$, Tatyana Goldberg $^{1 \dagger}$, Sebastian Seitz ${ }^{1}$, Mikael Bodén ${ }^{2}$ and Burkhard Rost ${ }^{1,3,4,5}$

\section{Correction to: BMC Bioinformatics (2019) 20:205 https://doi.org/10.1186/s12859-019-2790-9}

Following publication of the original article [1], the author reported that an incorrect figure has been published as Fig. 2. The correct Fig. 2 is shown below.

The publisher apologizes to the authors and readers for the inconvenience.

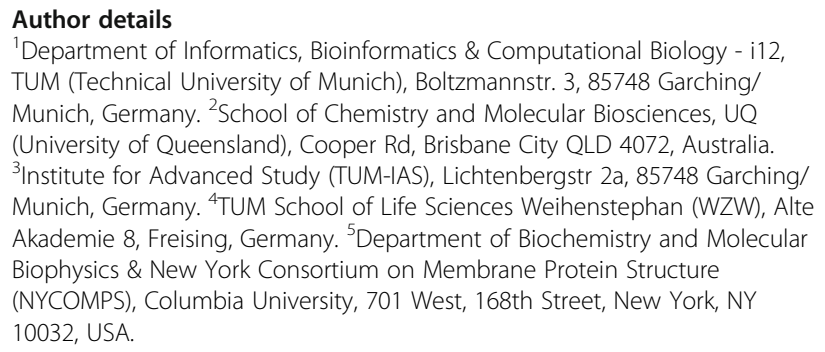

Published online: 20 December 2019

\section{Reference}

1. Littmann $M$, et al. Detailed prediction of protein sub-nuclear localization.

BMC Bioinformatics. 2019;20:205. https://doi.org/10.1186/s12859-019-2790-9.

\footnotetext{
The original article can be found online at https://doi.org/10.1186/s12859019-2790-9

*Correspondence: littmann@rostlab.org; assistant@rostlab.org

${ }^{\dagger}$ Maria Littmann and Tatyana Goldberg contributed equally to this work.

'Department of Informatics, Bioinformatics \& Computational Biology - i12,

TUM (Technical University of Munich), Boltzmannstr. 3, 85748 Garching/

Munich, Germany

Full list of author information is available at the end of the article
}

(c) The Author(s). 2019 Open Access This article is distributed under the terms of the Creative Commons Attribution 4.0 International License (http://creativecommons.org/licenses/by/4.0/), which permits unrestricted use, distribution, and reproduction in any medium, provided you give appropriate credit to the original author(s) and the source, provide a link to the Creative Commons license, and indicate if changes were made. The Creative Commons Public Domain Dedication waiver (http://creativecommons.org/publicdomain/zero/1.0/) applies to the data made available in this article, unless otherwise stated. 


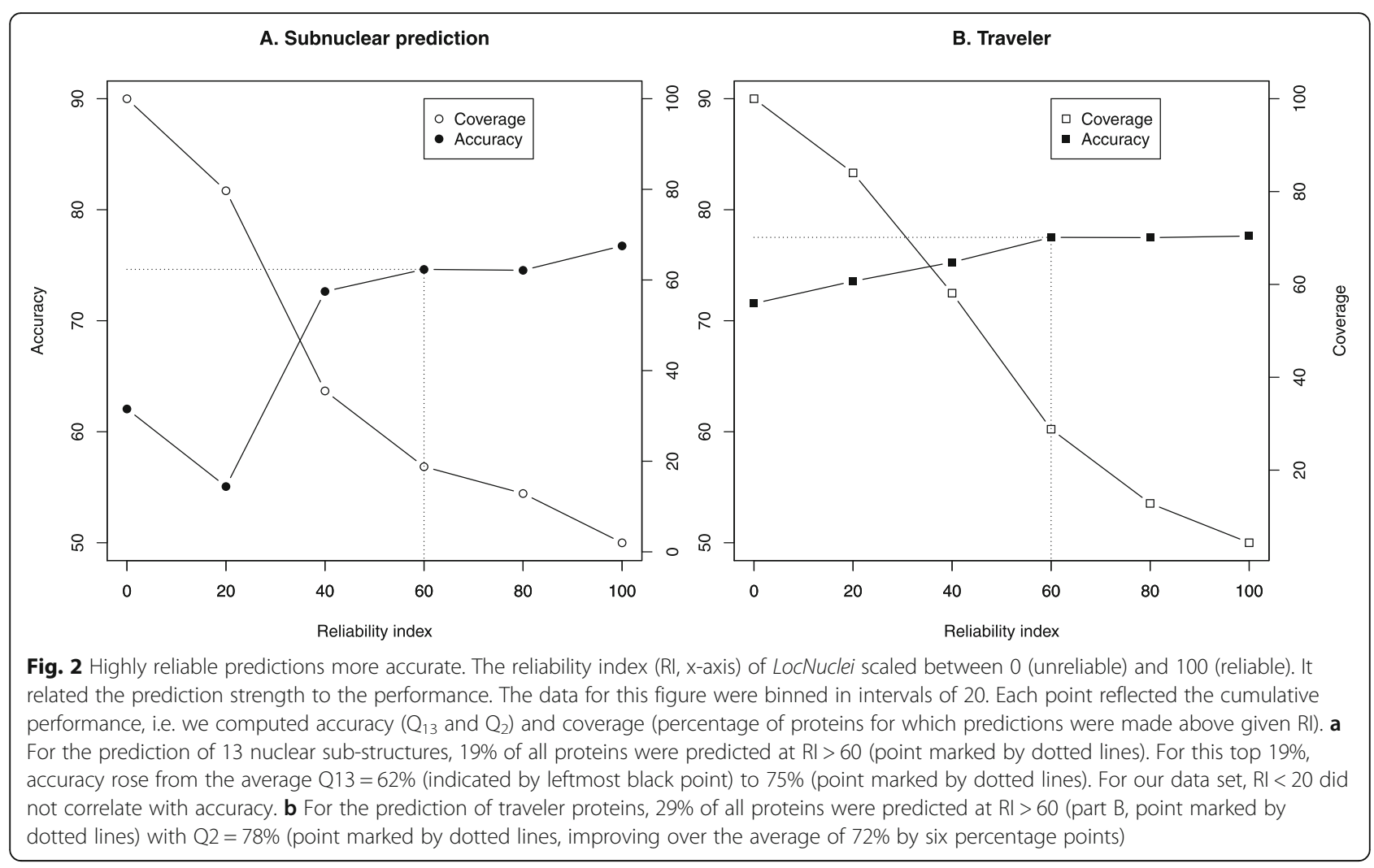

